\title{
Contribution to the natural history of Barbastella barbastellus in Turkey (Chiroptera: Vespertilionidae)
}

\author{
Př́íspěvek k biologii d'asíka černého (Barbastella barbastellus) v Turecku \\ (Chiroptera: Vespertilionidae)
}

\author{
Ahmet KARATAŞ ${ }^{1 *}$, Şafak BULUT ${ }^{2}$, Ayşegül KARATAŞ ${ }^{1}$, \\ Ferhat TOPRAK ${ }^{3} \&$ Şakir Önder ÖZKURT ${ }^{4}$ \\ ${ }^{1}$ Department of Biology, Faculty of Arts and Sciences, Niğde Ö. H. University, TR-51240 Niğde, \\ Turkey \\ ${ }^{2}$ Department of Molecular Biology and Genetics, Faculty of Arts and Sciences, Hitit University, TR-19040 \\ Çorum, Turkey \\ ${ }^{3}$ Ümitköy Anadolu İmam Hatip High School, TR-06510 Çankaya-Ankara, Turkey \\ ${ }^{4}$ Education Faculty, Ahi Evran University, TR-40100 Kırşehir, Turkey \\ *corresponding author: rousettus@hotmail.com
}

received on 18 May 2020

\begin{abstract}
The western barbastelle, Barbastella barbastellus (Schreber, 1774) is a species protected by national and international agreements. The number of records on its occurrence in Turkey is very limited, and the species is not well-known. Records in literature, except for the ones from Adiyaman (owl pellet), Kırklareli, and Nevşehir, are from northeastern Turkey. Here presented new findings show that the species is distributed predominantly in the areas along the Black Sea coast. According to call recording analyses, it was found also in western regions of Turkey including the Çanakkale and Denizli provinces. This study provides the first records of the species from southern and southwestern Turkey, the Bartın, Çanakkale, Denizli, and Konya Provinces. With respect to morphometric data, Turkish specimens represent the nominotypical form of $B$. barbastellus. We analysed three female specimens with the diploid number of chromosomes $2 \mathrm{n}=32$, with $\mathrm{NF}=54$ and $\mathrm{NFa}=50$. We also provide some ecological remarks, along with analyses of echolocation calls.
\end{abstract}

Key words. Barbastella barbastellus, distribution, karyotype, ecology, systematics, Turkey.

\section{INTRODUCTION}

The Palaearctic bat genus Barbastella Gray, 1821 was traditionally considered to represent two species, with a distribution ranging from Europe and North Africa to China and Japan; the western barbastelle, B. barbastellus (Schreber, 1774), described from Burgundy (France), and the eastern barbastelle B. leucomelas (Cretzschmar, 1830), described from the southern Sinai Peninsula (present Egypt). The Caspian barbastelle, Barbastella caspica Satunin, 1908 was originally described from the Pirsagat river valley near Kubaly (= Haciqabul, Qubalibalaoğlan) in present Azerbaijan as a subspecies of B. barbastellus, but is recently regarded as another species (KRUSKOP 2015). From Derjeeling (northeastern India), Plecotus darjelingensis Hodgson in Horsfield, 1855 was previously accepted as a race of Barbastella leucomelas, but 
is now regarded as a valid species, Barbastella darjelingensis. Additionally, two new species were described in the known range of the genus Barbastella, namely the Beijing barbastelle, B. beijingensis Zhang, Han, Jones, Lin, Zhang, Zhu, Huang et Zhang, 2007 from San-Liu-Shui in the Fangshan District, southwestern Beijing (Pekin) Province of China and the Japanese barbastelle, B. pacifica Kruskop, Kawai et Tiunov, 2019 from the Kunashir Island of Russia. Barbastella leucomelas s.str. is restricted in its distribution to both sides of the Red Sea in Arabia and Africa (Benda \& MLíkovský 2008, López-Baucells 2019).

Turkish records of the genus Barbastella were reviewed by BENDA \& HoRÁČEK (1998) and all of them referred to B. barbastellus. The species occurs mainly in Europe, from the north of the Iberian Peninsula to the Caucasus, and from southern Scandinavia and Latvia to some of the Mediterranean islands, Morocco, and the Canary Islands (MitCHELl-Jones et al. 1999, LÓPEZ-BAUCELLS 2019). Since only a low number of records exists, information about the species in Turkey is relatively limited. In this study, we aimed to provide a contribution to the distribution and karyology of $B$. barbastellus in Turkey, along with some ecological observations, description of echolocation, and the evaluation of its conservation status.

\section{MATERIAL AND METHODS}

\section{Sampling and morphology}

During our field trips between 2000 and 2020, a total of 14 individuals of Barbastella barbastellus were captured by mist-nets and hand-nets at five different localities in Turkey (Fig. 1), and examined with respect to morphological and karyological characteristics. Two females from Ülkü (Rize Province) and one female from Çamlık (Konya Province) were karyotyped following the colchicine hypotonic citrate technique of FORD \& HAMERTON (1956). The diploid number of chromosomes (2n), the fundamental number of chromosomal arms (NF), and the number of autosomal arms (NFa) were determined by examining the photographs of about 30 metaphase cells from each specimen. Centromere positions (metacentric, submetacentric, and acrocentric) were also recorded.

Eleven bats were prepared as standard museum specimens, dry skins with extracted skulls, while some individuals were released after taking their external measurements. Three bacula were extracted following TopÁL (1958). The skins, skulls, bacula, and karyotype preparations are deposited in the collection at the Department of Zoology, Niğde University (ZDNU).

All the adult individuals were weighed and measured (see Table 1). According to the ossification of wing fingers, all specimens were identified as adults, with the exception of a subadult female from the Balatini Cave. Along with the body weight (in grams), the external and cranial measurements (in millimetres) were taken by calliper with an accuracy of $1 \mathrm{~mm}$ and $0.1 \mathrm{~mm}$, respectively.

Abbreviations used in the text: $\mathrm{W}=$ weight, $\mathrm{TB}=$ total body length, $\mathrm{TL}=$ tail length, $\mathrm{HF}=$ hindfoot length, $\mathrm{EL}=$ ear length, $\mathrm{FA}=$ forearm length, $\mathrm{TA}=$ tibia length, $\mathrm{TrL}=$ tragus length, $\mathrm{TbL}=$ thumb length, GLS $=$ greatest length of skull, $\mathrm{CbL}=$ condylobasal length, $\mathrm{MB}=$ mastoid breadth, $\mathrm{BB}=$ braincase breadth, $\mathrm{ZB}=$ zygomatic breadth, $\mathrm{IC}=$ interorbital constriction, $\mathrm{RB}=$ rostral breadth, $\mathrm{HS}=$ height of skull, $\mathrm{ML}=$ mandible length, $\mathrm{C}-\mathrm{M}^{3}=$ maxillary tooth row length, $\mathrm{C}-\mathrm{M}_{3}=$ mandibular tooth row length.

\section{Echolocation calls}

Ultrasound recordings were obtained using D500X Ultrasound Detector/Recorder Mk I (Pettersson Elektronik AB, Uppsala, Sweden), hanging on average 3 meters above ground. Triggering system of the detector automatically detected sounds and recorded ultrasound calls during acoustic surveys in Elmalı (Antalya Province) on 26-27 October 2019, Üçpınar (Çanakkale Province) on 19-24 June 2019 and 21-25 May 2020, and also Babadağ (Denizli Province) on 28-30 October 2019 and 8 June 2020. 
More than 5,000 call sequences were recorded and analysed. A part of the recorded ultrasounds contains background noises including those of insects and mechanical sounds. The majority of ultrasounds suitable for analysis belonged to other bat species such as Eptesicus serotinus (Schreber, 1774) and Nyctalus leisleri (Kuhl, 1817). Fifty sequences with 124 bat call pulses were evaluated, and the presence of the western barbastelle was determined via sound recordings with sufficient (90-99\%) quality, taken only in Üçpınar and Babadağ.

BatExplorer 2.1 (Elekon AG, Switzerland) and BatSound 4.0 (Pettersson) software packages were used for the analysis of recorded echolocation sounds. In the analysis, four bioacoustic parameters were measured for each call: $\mathrm{F}_{\text {start }}$ (start frequency at the onset of the call), $\mathrm{F}_{\max }$ (peak frequency: frequency of maximum energy), $\mathrm{F}_{\text {end }}$ (finish frequency measured at the end of the call), and pulse duration (call length). Nevertheless, we did not take inter-pulse intervals (from the start of one call to the start of the next call, i.e. the duration between two consecutive calls in a sequence), since it was variable $(83.8-113.0 \mathrm{~ms})$.

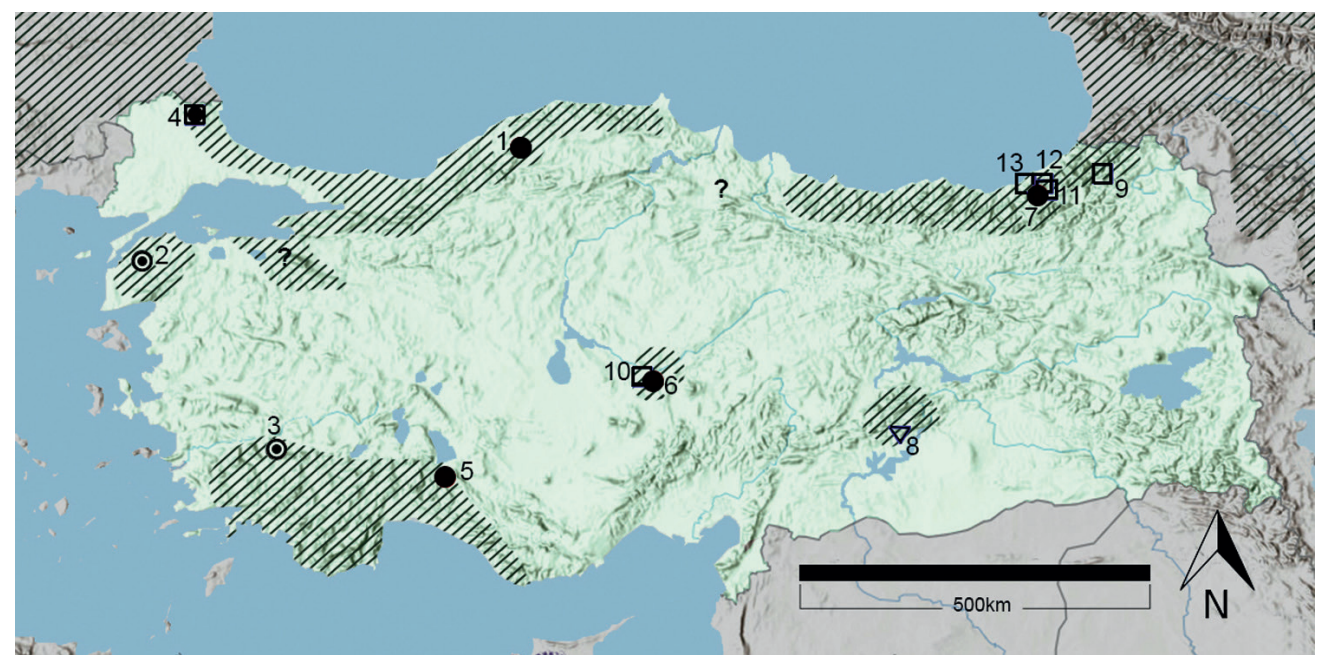

Fig. 1. Records of Barbastella barbastellus in Turkey $(-$ new sampling localities, $\odot-$ new echolocation recordings); literature data ( $\square$ - sampling, $\nabla$ - owl pellet findings) after von HeLversen (1989), Obuch (1994), Steiner \& Gaisler (1994), and Benda \& HoráČeK (1998): 1. Bartın Province: Uluyayla; 2. Çanakkale Province: Üçpınar; 3. Denizli Province: Babadağ; 4. Kırklareli Province: Sarpdere, Dupnisa Cave; 5. Konya Province: Çamlık, Balatini Cave; 6. Nevşehir Province: Mustafapaşa; 7. Rize Province: Ülkü; 8. Adıyaman Province: Karadut; 9. Artvin Province: Ardanuç; 10. Nevşehir Province: Göreme; 11. Rize Province: Köprübaşı; 12. Rize Province: Şenyuva; 13. Rize Province: Çamlıtepe. The distribution range in the Caucasus and Balkans was modified after BENDA et al. (2003) and KRUSKOP (2015).

Obr. 1. Nálezy d’asíka černého (Barbastella barbastellus) v Turecku $(-$ nové nálezy netopýrů, $\odot$ - nové záznamy echolokačních hlasů); publikované nálezy ( $\square$ - nálezy netopýrů, $\nabla$ - nálezy z vývržků sov) podle von Helversena (1989), Obucha (1994), Steinera \& Gaislera (1994) a Bendy \& HoráčKa (1998): 1. Parthenijská provincie: Uluyayla; 2. Dardanelská province: Üçpınar; 3. Denizelská provincie: Babadağ; 4. Kirklarelská provincie: Sarpdere, jeskyně Dupnisa; 5. Ikonijská provincie: Çamlık, jeskyně Balatini; 6. Neapolská provincie: Mustafapaşa; 7. Rizenská provincie: Ülkü; 8. Adijamanská provincie: Karadut; 9. Artvinská provincie: Ardanuç; 10. Neapolská provincie: Göreme; 11. Rizenská provincie: Köprübaş1; 12. Rizenská provincie: Şenyuva; 13. Rizenská provincie: Çamlıtepe. Areál rozšíření na Kavkaze a Balkánském poloostrově byl pozměněn podle BENDY et al. (2003) a KRUSKOPA (2015). 
Table 1. The external and cranial measurements, and weight of adult Barbastella barbastellus specimens; $\mathrm{n}=$ number of examined specimens, $\mathrm{SD}=$ standard deviation; for the character acronyms see Methods Tab. 1. Vnější a lebeční míry, včetně hmotnosti, dospělých jedinců d'asíka černého (Barbastella barbastellus) z Turecka; $\mathrm{n}=$ počet šetřených jedinců, mean = průměr, range = rozmezí hodnot, $\mathrm{SD}=$ standardní odchylka; zkratky rozměrů viz Methods

\begin{tabular}{|c|c|c|c|c|c|c|c|c|}
\hline \multirow[b]{2}{*}{ character } & \multirow[b]{2}{*}{$\mathrm{n}$} & \multicolumn{3}{|c|}{ Ülkü (Rize Province), 7 우 } & \multicolumn{4}{|c|}{ Dupnisa (Kirklareli Province), $3 \hat{\partial} \widehat{\partial}$} \\
\hline & & mean & range & $\mathrm{SD}$ & $\mathrm{n}$ & mean & range & SD \\
\hline TB & 7 & 103.0 & $99.0-108.0$ & 3.16 & 3 & 103.0 & $102.0-104.0$ & 1.00 \\
\hline TL & 7 & 50.7 & $49.0-55.0$ & 2.21 & 3 & 47.7 & $46.0-49.0$ & 1.53 \\
\hline $\mathrm{HF}$ & 7 & 7.6 & $7.0-8.0$ & 0.35 & 3 & 7.7 & $7.5-8.0$ & 0.29 \\
\hline EL & 7 & 15.86 & $14.5-17.5$ & 0.94 & 3 & 15.17 & $14.5-15.5$ & 0.58 \\
\hline W & 7 & 6.97 & $6.3-8.0$ & 0.54 & 3 & 7.94 & $7.3-9.0$ & 0.92 \\
\hline FA & 7 & 41.00 & $40.0-42.5$ & 0.96 & 5 & 39.10 & $38.2-40.5$ & 0.89 \\
\hline TA & 7 & 20.71 & $20.0-22.0$ & 0.81 & 3 & 20.17 & $20.0-20.5$ & 0.29 \\
\hline $\operatorname{TrL}$ & 6 & 9.25 & $9.0-10.0$ & 0.42 & 3 & 9.00 & $9.0-9.0$ & 0.00 \\
\hline $\mathrm{TbL}$ & 7 & 5.36 & $5.0-5.5$ & 0.24 & 3 & 5.67 & $5.5-6.0$ & 0.29 \\
\hline GLS & 7 & 14.74 & $14.6-14.9$ & 0.11 & 3 & 14.60 & $14.6-14.6$ & 0.00 \\
\hline $\mathrm{CbL}$ & 7 & 13.60 & $13.2-13.9$ & 0.24 & 3 & 13.50 & $13.5-13.5$ & 0.00 \\
\hline MB & 7 & 8.17 & $8.1-8.3$ & 0.08 & 3 & 8.25 & $8.1-8.4$ & 0.21 \\
\hline $\mathrm{BB}$ & 7 & 7.19 & $7.1-7.2$ & 0.04 & 3 & 7.30 & $7.2-7.4$ & 0.14 \\
\hline $\mathrm{ZB}$ & 7 & 7.36 & $7.2-7.5$ & 0.14 & 3 & 7.60 & $7.4-7.8$ & 0.28 \\
\hline IC & 7 & 3.60 & $3.5-3.7$ & 0.06 & 3 & 3.65 & $3.6-3.7$ & 0.07 \\
\hline $\mathrm{RB}$ & 7 & 3.81 & $3.7-3.9$ & 0.09 & 3 & 3.90 & $3.9-3.9$ & 0.00 \\
\hline HS & 7 & 6.80 & $6.6-7.0$ & 0.14 & 3 & 6.80 & $6.8-6.8$ & 0.00 \\
\hline ML & 7 & 9.54 & $9.4-9.7$ & 0.10 & 3 & 9.45 & $9.4-9.5$ & 0.07 \\
\hline $\mathrm{C}-\mathrm{M}^{3}$ & 7 & 4.61 & $4.5-4.7$ & 0.09 & 3 & 4.55 & $4.4-4.7$ & 0.21 \\
\hline $\mathrm{C}-\mathrm{M}_{3}$ & 7 & 5.11 & $5.0-5.3$ & 0.12 & 3 & 5.15 & $5.1-5.2$ & 0.07 \\
\hline
\end{tabular}

For the identification of calls of B. barbastellus, we used sound recordings from Europe and the descriptions given in literature (Rydell \& Bogdanowicz 1997, Schober \& Grimmberger 1997, Vaughan et al. 1997, DenZINGER et al. 2001, OBRIST et al. 2004). In addition, the calls we recorded were compared to those of a related species, B. leucomelas, given by BENDA et al. (2010) and HACKETT et al. (2016).

\section{RESULTS AND DISCUSSION}

\section{External and cranial characters}

The fur is dense and woolly, with hair dark grey or blackish at the base. The back is light smoky-grey, partially with yellowish (brownish beige or greyish light brown) tinge above. The underside is pale and yellowish dirty white or light grey, with beige tips. Base of hair is dark grey. The muzzle is pink-brown or flesh pink, the ears and wing membranes are grey-brown. Dental formula is 2.1.2.3 / 3.1.2.3 = 34.

The western barbastelle is a medium-sized vespertilionid bat species, with a maximum TBL of $108 \mathrm{~mm}$. External measurements along with weights are given in Table 1. Ears are long, with a maximum value of $17.5 \mathrm{~mm}$. A long, triangular and pointed tragus reaches up to more than half the length of pinna (Fig. 2). 
According to López-BAucells (2019), females are larger than males. However, females in our collection were slightly larger than males in terms of some measurements such as TL, EL, FA, TA, TrL; but smaller than males in terms of other measurements such as HF, RB, IC, and $\mathrm{W}$, with respect to our collection. Although differences between females and males are not statistically significant, external and cranial measurements in Table 1 were given separately for comparison of sexes.

Barbastella barbastellus is represented by the nominate form in its whole distribution range, with the exceptions of the Canary Islands (ssp. guanchae) and Iran (undescribed subspecies). The size parameters of the Turkish samples are consistent with B. barbastellus barbastellus (Schreber, 1774) characteristics, according to MACDonAld \& BARRETT (1993), Rydell \& Bogdanowicz (1997), Schober \& Grimmberger (1997), and López-Baucells (2019).

\section{B a c u $1 \mathrm{um}$}

The baculum in Turkish Barbastella barbastellus is basally wide and laterally thin (Fig. 3). The mean length of baculum is $0.80 \mathrm{~mm}$ (range $0.75-0.85 \mathrm{~mm} ; \mathrm{n}=3$ ), and the mean width of the proximal epiphysis is $0.30 \mathrm{~mm}$. The metric characters of bacula from Turkish B. barbastellus were consistent with those given in Topál (1958), Hill \& HARrison (1987), and Rydell \& BogdANOWICZ (1997).

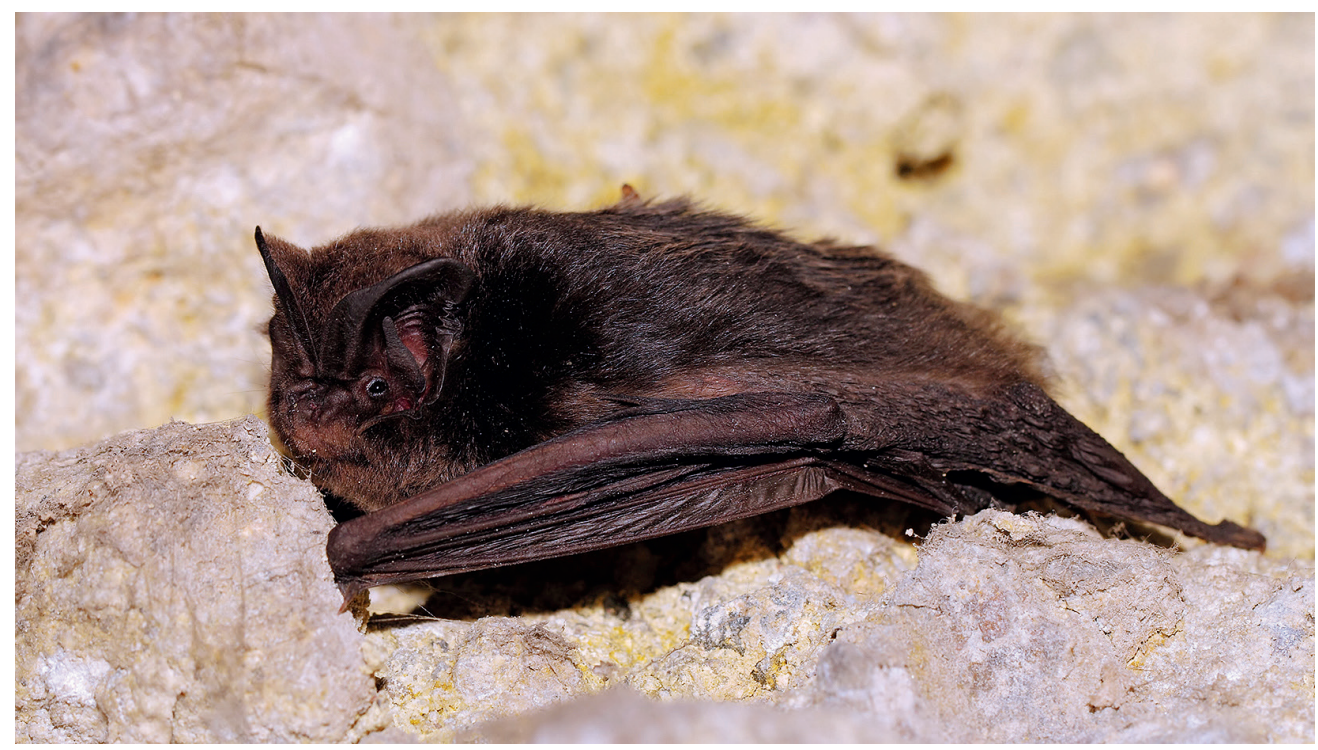

Fig. 2. An adult male Barbastella barbastellus caught at Mustafapaşa (Nevşehir Province, central Turkey) on 9 October 2011.

Fig. 2. Dospělý samec d'asíka černého (Barbastella barbastellus) odchycený a vypuštěný 9. ř́inna 2011 u vsi Mustafapaša v Neapolské provincii, střední Turecko. 


\section{Ka r y o log y}

The diploid number of chromosomes (2n) is 32. The autosomal set consists of eight (seven large and one small) pairs of metacentric, two large pairs of submetacentric, and five small pairs of acrocentric chromosomes. Two pairs of acrocentric chromosomes are dot-like. The X chromosome is large metacentric, and the Y chromosome is dot-like acrocentric / punctiform. The NF and NFa were found as 54 and 50, respectively (Fig. 4).

Karyological studies of B. barbastellus were made by Bovey (1949) in Switzerland, CAPANNA et al. (1968) in Italy, Zima (1978) in former Czechoslovakia, and Volleth (1985) and KARATAȘ et al. (2004) in northern Turkey. A banded chromosome study on this species was published by Volleth (1987).

The morphology of sexual chromosomes is submetacentric for the X, and acrocentric for the Y. Bovey (1949), CAPAnNa et al. (1968), and Karataș et al. (2004) found the same results, except for one pair of the microchromosomes that was considered as biarmed by ZIMA (1978), and the $\mathrm{X}$ as submetacentric by FEDYK \& RUPRECHT (1983) (Table 2). With respect to the numbers of diploid chromosomes and autosomal chromosomal arms, this karyotype is almost identical to those of the Turkish Plecotus species (Karataș et al. 2003). Volleth (1985) also reported that the banding patterns of $B$. barbastellus were almost identical with those of Plecotus auritus (Linnaeus, 1758). Similar results for banding patterns of chromosomes of B. barbastellus and P. auritus were given by Fedyk \& Ruprecht (1983) as well as Volleth \& Heller (1994).

\section{Distribution}

New records of Barbastella barbastellus in Turkey came from seven different localities (Fig. 1). Most of them were made in the Bartın, Çanakkale, Kırklareli, and Rize Provinces, all of which are located in the northern part of the country. Only one was from Central Anatolia, made in the
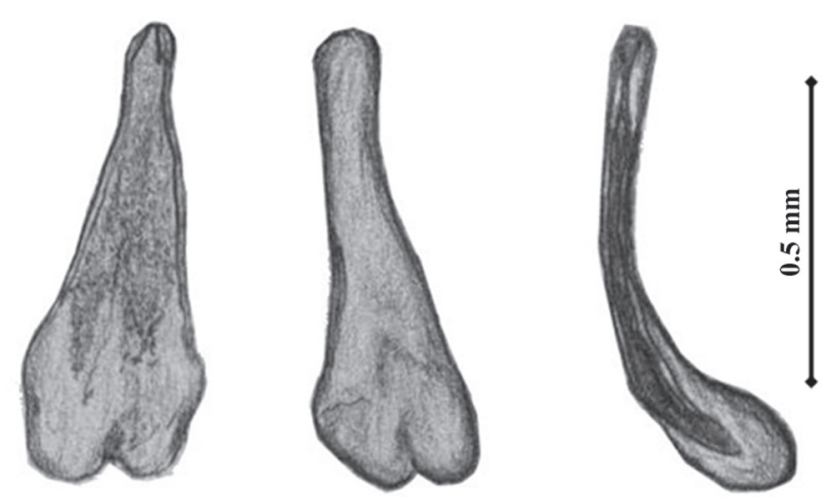

Fig. 3. Dorsal view (a), ventral view (b), and lateral view (c) of the baculum of Barbastella barbastellus from Turkey.

Obr. 3. Hřbetní (a), břišní (b) a stranový (c) pohled na penisovou kost d'asíka černého (Barbastella barbastellus) z Turecka. 
Table 2. Comparison of the results of chromosome analysis of Barbastella barbastellus from Turkey with those given in previously published studies; $2 \mathrm{n}=$ diploid number of chromosomes, $\mathrm{NF}=$ fundamental number of chromosomal arms, $\mathrm{NFa}=$ number of autosomal arms, $\mathrm{M}+\mathrm{SM}=$ number of metacentric and submetacentric chromosomes, $\mathrm{A}=$ number of acrocentric chromosomes, $\mathrm{X}, \mathrm{Y}=$ type of the sex chromosome

Tab. 2. Srovnání výsledků analysy chromosomů d’asíka černého (Barbastella barbastellus) z Turecka $\mathrm{s}$ výsledky uvedenými v publikovaných studiích; $2 \mathrm{n}=$ diploidní počet chromosomů, $\mathrm{NF}=$ základní počet chromosomálních ramen, $\mathrm{NFa}=$ počet autosomálních ramen, $\mathrm{M}+\mathrm{SM}=$ počet metacentrických a submetacentrických chromosomů, $\mathrm{A}=$ počet akrocentrických chromosomů, $\mathrm{X}, \mathrm{Y}=$ typ pohlavního chromosomu

\begin{tabular}{|c|c|c|c|c|c|c|c|c|}
\hline $2 n$ & $\mathrm{M}+\mathrm{SM}$ & A & $\mathrm{D}_{\mathrm{M}}$ & $\mathrm{D}_{\mathrm{A}}$ & $\mathrm{NFa}$ & $X$ & Y & reference / zdroj \\
\hline 32 & 20 & 6 & - & 4 & 50 & M & A & $\begin{array}{l}\text { Bovey 1949, CAPANNA } \\
\text { et al. } 1968, \text { KarATAŞ et } \\
\text { al. } 2004\end{array}$ \\
\hline 32 & 20 & 6 & 2 & 2 & 52 & M & A & ZIMA 1978 \\
\hline 32 & 20 & 6 & - & 4 & 50 & SM & A & $\begin{array}{l}\text { FEDYK \& RUPRECHT } \\
1983\end{array}$ \\
\hline 32 & 20 & 6 & - & $?$ & 52 & SM & A & VoLLETH 1985 \\
\hline 32 & 20 & 6 & - & 4 & 50 & M & - & this study / tento spis \\
\hline
\end{tabular}

Nevşehir Province. The other two localities (in Konya and Denizli Provinces) lie in southwestern Anatolia. The records of $B$. barbastellus from Sarpdere (Kirklareli Province) and Ülkü (Rize Province) were already reported previously by BENDA \& HoRÁČEK (1998) and STEINER \& GAISLER (1994), respectively. Other records represent new occurrence sites.

In addition to our distributional records, this species was previously recorded in Turkey by von Helversen (1989), Steiner \& Gaisler (1994), and Benda \& Horáček (1998). However, SteINER \& GAISLER (1994) did not publish their records from 1967 and 1968 for a long time and ÇAĞLAR (1969) gave a record from Hemşin (as H. STEINER, unpublished) without exact locality. The southernmost point of distribution for Barbastella barbastellus in Turkey was reported by Овисн (1994) from an owl pellet collected in the Adryaman Province. BENDA \& HorÁčEK (1998) reviewed all published records, with the exception of Köprübaşı (Rize Province) by STEINER \& GAisler (1994).

Distribution records are presented below, with the province names in italics.

New DATA. Bartın: Uluyayla, Karlık Cave [1] (in border with Karabük: Eflani), 20 January 2001: 1 ad. (leg. A. ÖzGÜL). - Çanakkale: Üçpınar [2], 19-24 June 2019: echolocation calls (rec. Ş. Ö. ÖZKURT). Denizli: Babadağ [3], 26-30 October 2019: echolocation calls (rec. Ş. Ö. ÖZKURT). - Kırklareli: Sarpdere, Dupnisa Cave [4], 22 September 2001: net. 3 ô ${ }^{\lambda}$ ad. (ZDNU 2001/197-198, 2001/199 [ND1 haplotype KF218433 in the GenBank]); 13 June 2003: 1 ad., 14 June 2003: 1 o ad. (leg. C. Dietz \& I. Schunger). - Konya: Çamlık, Balatini Cave [5], 7 March 2008: 1 q sad. (leg. Ş. Bulut). - Nevşehir: Mustafapaşa [6], 9 October 2011: 1 ad. (released [ND1 haplotype KF218431 in the GenBank]; leg. A. Karataș, E. ÇORAMAN \& E. ÇELIK). - Rize: Ülkü [7], house, 25 August 2001: colony of 20 inds., incl. 7 우 ad. (ZDNU 2001/118-123, 2001/117 [ND1 haplotype KF218432 in the GenBank]).

Published ReCords. Adiyaman: Karadut [8], cave, 1300 m a. s. 1., 7 June 1992: remains of 1 ind. from Strix aluco pellets (Овисн 1994). - Artvin: north of Ardanuç [9], cave in a canyon, 12 August 1983: 1 o ad. (von Helversen 1989, cf. Volleth 1985). - Kırklareli: Sarpdere [4], Dupnisa Cave, 16 October 1993: 

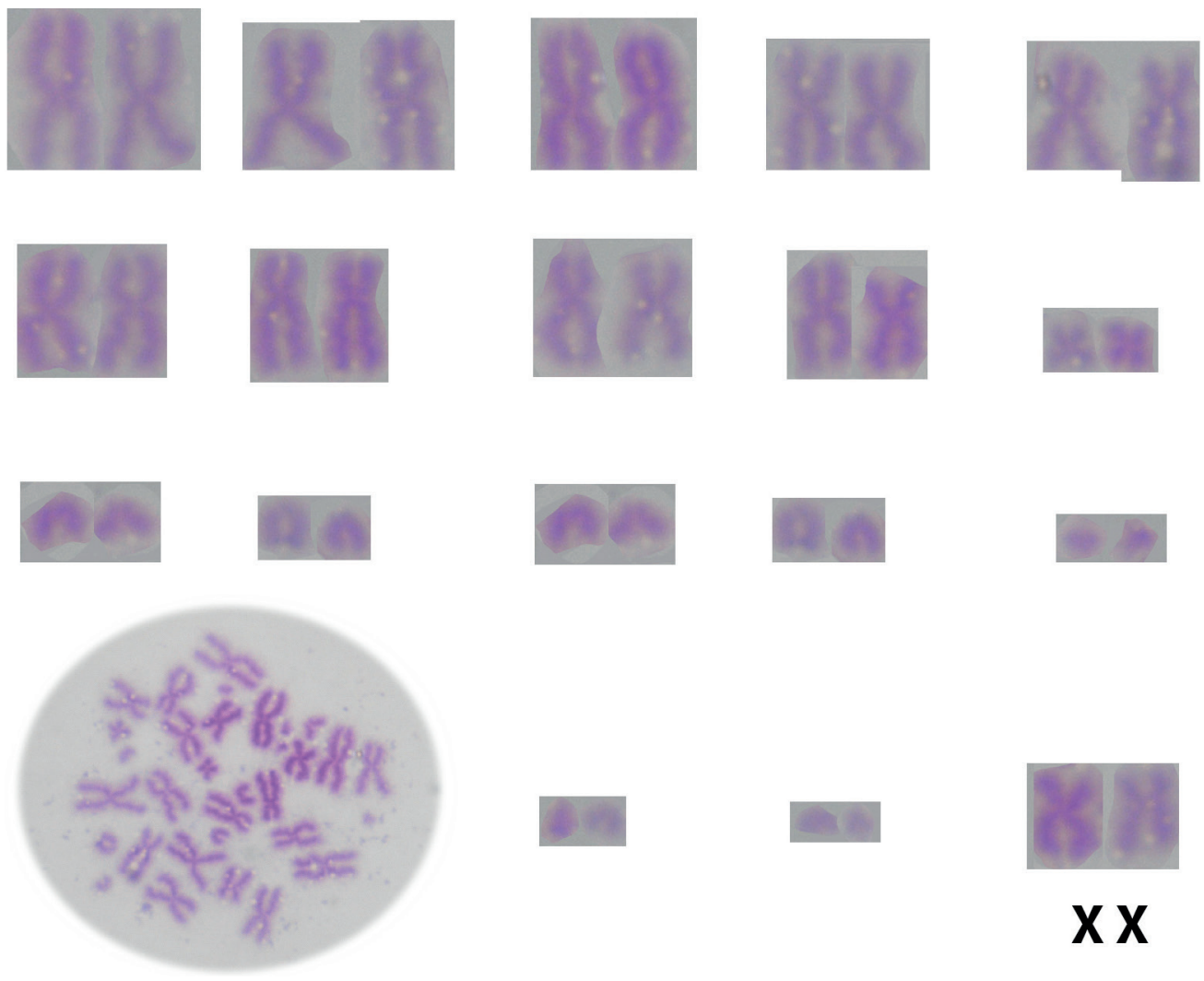

Fig. 4. Karyotype of female Barbastella barbastellus from the Balatini Cave near Çamlık (Konya Province); for details see Table 2 .

Obr. 4. Karyotyp samice d'asíka černého (Barbastella barbastellus) odchycené v jeskyni Balatini u Čamliku v Ikonijské provincii; podrobnosti viz tab. 2.

net. 5 $\widehat{\delta}$ ad., 5 q $q$ ad. (BENDA \& HorÁČEK 1998). - Nevşehir: 500 m northeast of Göreme [10], cave, 26 July 1996: net. 1 + ad. (BENDA \& HORÁČEK 1998). - Rize: Köprübaşı [11], 450 m a. s. 1., 1 ind. (STEINER

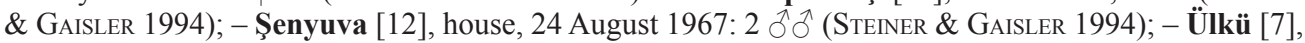

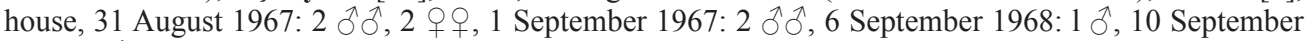
1968: 1 ô (STEINER \& GAISLER 1994); - Çamlıtepe "Soğa (= Zua)" (near Akyamaç "Tezine") [13], house, 6 September 1968: 1 đ (Steiner \& Gaisler 1994, cf. Kumerloeve 1975, ÇaĞLAr 1969; given as "Hemşin (= Ortaköy)" by the latter author).

So far, the western barbastelle has been very rarely found along the easternmost Black Sea and the Turkish Thrace (von Helversen 1989, Steiner \& Gaisler 1994, Benda \& HoráčeK 1998). Since its main range is centered to the European temperate broadleaf and mixed forests, Barbastella barbastellus is more common in the northern forested parts of Turkey. Distributional 
records show that there are isolated and quite inabundant vicariant populations in the central and southern regions of the country.

\section{Ecological remarks}

The western barbastelle lives in woodlands, and is a predominantly tree-dwelling species associated with old mature forests with dead or storm-damaged trees. It also roosts in caves near water and buildings, and hibernates in caves, tunnels, and cellars (SCHOBER \& Grimmberger 1997, Mitchell-Jones et al. 1999, Sierro 1999, López-Baucells 2019). Three of our six records (in the Bartın, Kırklareli, and Konya Provinces) were from natural caves, and one from the Nevşehir Province was from an ancient artificial cave. As the record from the Bartın Province was taken in mid-January and the record from the Konya Province was taken in the beginning of March, bats were possibly hibernating inside the caves. The record from the Nevşehir Province was made at night on 9 October. The bat was found in a deep end of a cave, in the state of torpor, and thus might have entered the cave for the purpose of an early hibernation. However, the bats from the Kirklareli Province were captured on 22 September, a date when bats are in their active period, and even the mating behaviour is still ongoing. The Dupnisa Cave, hosting the highest number of bat species in Turkey was scanned thoroughly during the day, from the bottom entrance until the top entrance but not a single barbastelle was encountered inside the cave system. A net was set at the cave entrance towards evening, before the bats came out, and three individuals were captured trying to exit the cave. The fact that they came to the entrance from the inside made us think that they spent the day hours in the cave, increasing the possibility

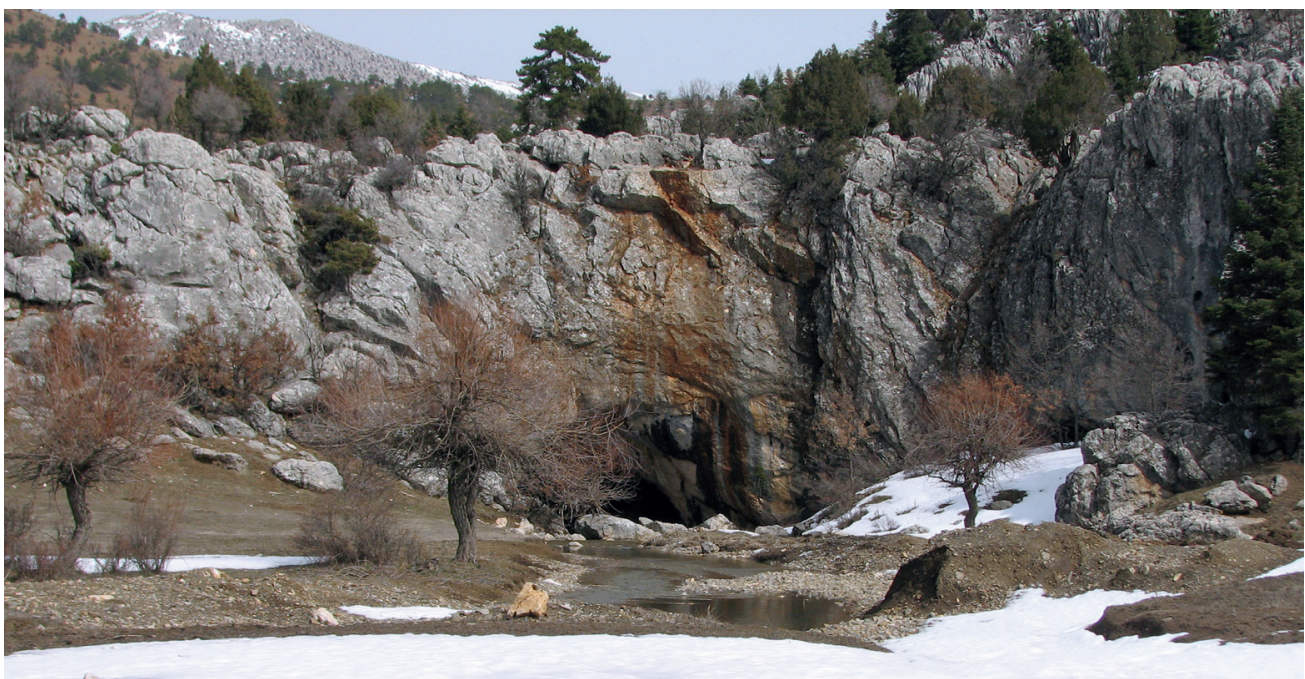

Fig. 5. The Balatini Cave near Çamlık in the Taurus Mts., Konya Province, southern Turkey.

Obr. 5. Jeskyně Balatini u Çamliku v pohoří Taurus, Ikonijská provincie, jižní Turecko. 
that they roosted in the cave. Only in the Rize Province, we also found a summer roost of about 20 individuals behind the wooden window shutters of an old house.

The locality in central Anatolia was in a steppe habitat, apart from sparse woodlands such as poplar (Populus spp.) stands in the valleys. However, record localities from the northeastern and western parts of Turkey are largely inside forests (unlike the steppe habitat in the Nevşehir Province). The Dupnisa Cave is located in a deciduous forest (predominantly oaks - Quercus spp.); Ülkü (Rize Province) is situated in a mixed forest of broad-leaved trees (oaks - Quercus spp., hornbeam - Carpinus betulus, and beech - Fagus orientalis) with conifers (Caucasian spruce - Picea orientalis); Üçpınar (Çanakkale Province) lies also in a mixed forest composed predominantly of oaks - Quercus spp. and the Turkish pine - Pinus brutia; Uluyayla (Bartın Province) has a coniferous forest mainly with the Caucasian fir - Abies nordmanniana; Babadağ (Denizli Province) is a bare mountainous terrain about $500 \mathrm{~m}$ away from a black pine (Pinus nigra) forest, at an altitude of 1,595 m a. s. 1.; and the Balatini Cave (Konya Province) has a vegetation predominantly consisting of the cedar (Cedrus libani) and juniper (Juniperus spp.), at an altitude of 1,407 $\mathrm{m}$ a. s. 1. (Fig. 5). These findings showed that the species has a wide habitat tolerance in Turkey, at the southern limits of its distribution range.

The altitudes of 13 localities in Turkey (including the literature data) range from $389 \mathrm{~m}$ to $1,595 \mathrm{~m}$ a. s. 1 ., the median being $810.0 \mathrm{~m}$ a. s. 1 . and mean $868.2 \mathrm{~m}$ a. s. 1 . The approximate altitudes of Turkish records are as follows: Sarpdere 389 m a. s. 1., Köprübaş1 400 m a. s. 1., Şenyuva 480 m a. s. 1., Çamlıtepe 490 m a. s. 1., Artvin 500 m a. s. 1., Ülkü 710 m a. s. 1., Üçpınar 810 m a. s. 1., Uluyayla 975 m a. s. 1., Göreme 1,070 m a. s. 1, Mustafapaşa 1,160 m a. s. 1., Karadut 1,300 m a. s. 1., Çamlık 1,407 m a. s. 1., Babadağ 1,595 m a. s. 1.

In Austria, the known localities range from 170 to 1,990 m a.s.l., but are concentrated in the submontane and montane belt (Mitchell-Jones et al. 1999). Similarly, Schober \& Grimmberger (1997) noted that the species prefers forested foothills and mountains, but also occurs in towns. In summer, it has been recorded at the altitudes up to $1,923 \mathrm{~m}$ a. s. 1 . in the Alps, and the highest maternity roost was reported at $1,100 \mathrm{~m}$ a. s. 1 . in the Czech Republic. However, López-BAucells (2019) gave the altitude range for this bat from the sea level up to 2,260 $\mathrm{m}$ a. s. 1.

It was observed near the Dupnisa Cave that the barbastelles emerged from the roosts in early evening, and that the bat typically flew low above the ground, while sometimes feeding at the treetop height. This bat feeds mainly on Lepidoptera; but its diet also consists of Diptera in very low proportions, as well as Trichoptera, Neuroptera, Homoptera, and Hymenoptera, while Coleoptera and Araneae are even less frequent (Rydell \& Bogdanowicz 1997, Schober \& Grimmberger 1997, Sierro 1999, Mitchell-Jones et al. 1999, López-Baucells 2019). In Turkey, its feeding biology was previously unknown. Therefore, faeces belonging to a female captured in the Rize Province on 25 August and two males obtained in the Kurklareli Province on 22 September were analysed (WhitaKer \& Karataș 2009). Accordingly, the faeces of the males contained $100 \%$ Lepidoptera, while those of the female contained $95 \%$ of Lepidoptera and $3 \%$ of Coleoptera, possibly Curculionidae.

In the single day roost discovered in the Rize Province, barbastelles formed a cluster of about 20 individuals at the end of August. All of them were adult females. There is a high probability it was a remnant of a maternity colony, but no juvenile or subadult was found among them. One solitary barbastelle was found hibernating in each of the Karlık Cave (Bartın-Karabük Provinces border) and the Balatini Cave (Konya Province).

Since a simultaneous flight was observed near the Dupnisa Cave on 22 September, we may say that the mating probably took place in autumn. In three males captured at the entrance to 
the cave, the testicles were quite swollen, and the measurements for testicle length and width from these specimens were $5 \times 3 \mathrm{~mm}, 6 \times 3 \mathrm{~mm}$, and $6 \times 3 \mathrm{~mm}$, respectively.

\section{Echolocation calls}

The sounds belong to bats that fly in an open area at an average height of 7-8 $\mathrm{m}$ and are of two FM types. According to this, the average values for Barbastella barbastellus echolocation calls (Fig. 6) recorded in Üçpınar (Çanakkale Province) and Babadağ (Denizli Province) were as follows: the maximum frequency $\left(\mathrm{F}_{\text {start }}\right)$ varied between 30.7 and $57.1 \mathrm{kHz}$, minimum frequency $\left(\mathrm{F}_{\text {end }}\right)$ between 22.9 and $32.7 \mathrm{kHz}$, peak frequency $\left(\mathrm{F}_{\max }\right)$ between 24.1 and $42.5 \mathrm{kHz}$, and call duration between 1.6 and $7.8 \mathrm{~ms}$.

Barbastella barbastellus is one of the easiest European species to identify based on its echolocation calls. It emits alternative calls of two different signal types at different frequencies and amplitudes, similarly as B. leucomelas and B. caspica in the Middle East (Rydell \& BoGdanowicz 1997, Schober \& Grimmberger 1997, Vaughan et al. 1997, Denzinger et al. 2001, OBrist et al. 2004, Benda et al. 2006, 2010, 2012, HaCKeTt et al. 2016, López-BAucells 2019). These differences are partially caused by head movements and activity types in various habitats. Therefore we divided these acoustic parameters into two groups, giving average, minimum and maximum values. As shown in Table 3, the values of the call type I lie at ca. $57-23 \mathrm{kHz}$, with 1.6-3.9 ms of pulse durations, and the second type at ca. 49-25 kHz, with 4.1-7.8 ms of pulse durations. LóPEz-BAUCELls (2019) stated that the first call was always louder and ranged at $37-30 \mathrm{kHz}$, with ca. $46 \mathrm{kHz}$ of $\mathrm{F}_{\text {start }}$, ca. $28.4 \mathrm{kHz}$ of $\mathrm{F}_{\text {end }}$, and 1-5 ms of pulse durations; while the type II ranged at 43-30 kHz. VAUGHAN et al. (1997) gave the following average values for the western barbastelle echolocation calls: $\mathrm{F}_{\text {start }} 46.0 \mathrm{kHz}, \mathrm{F}_{\max } 36.8 \mathrm{kHz}, \mathrm{F}_{\text {end }} 28.4 \mathrm{kHz}$, and call duration $4.4 \mathrm{~ms}$.

All of these values fall within the range of our minimum-maximum values. ScHOBER \& GRIMMBERGER (1997) wrote that type I was a loud, short CF/FM call of 35-28 kHz, with a duration of $4 \mathrm{~ms}$; whereas the signal type II was a soft, short CF/FM call of $43-33 \mathrm{kHz}$, with a duration of $5.2 \mathrm{~ms}$. Both calls began with a CF component of 1-1.5 ms duration. The maximum impulse intensity for the two types was at $35-30 \mathrm{kHz}$ and $43 \mathrm{kHz}$, respectively. Calls were repeated at 110-120 ms intervals. With respect to our recordings, the mean values of the duration of intervals were $102.4 \mathrm{~ms}$ for the call type I and $122.3 \mathrm{~ms}$ for the call type II. On the other hand,

Table 3. Parameters of echolocation calls of Barbastella barbastellus from Turkey; $\mathrm{F}_{\text {start }}=$ start (maximum) freqency $(\mathrm{kHz}), \mathrm{F}_{\max }=$ maximum energy (peak) frequency $(\mathrm{kHz}), \mathrm{F}_{\text {end }}=$ end (minimum) frequency $(\mathrm{kHz})$, pulse length $=$ call duration $(\mathrm{ms})$

Tab. 3. Parametry echolokačních výkřiků d'asíka černého (Barbastella barbastellus) $\mathrm{z}$ Turecka; $\mathrm{F}_{\text {start }}=$ počáteční (nejvyšší) frekvence $(\mathrm{kHz}), \mathrm{F}_{\max }=$ maximální energií obdařená (vrcholová) frekvence $(\mathrm{kHz})$, $\mathrm{F}_{\text {end }}=$ koncová (nejnižší) frekvence $(\mathrm{kHz})$, pulse length = délka výkřiku (ms)

\begin{tabular}{lccccc}
\hline call & $\mathrm{n}$ & $\mathrm{F}_{\text {start }}$ & $\mathrm{F}_{\max }$ & $\mathrm{F}_{\text {end }}$ & pulse length \\
\hline type I & 88 & $40.00 \pm 6.46$ & $33.21 \pm 4.40$ & $27.71 \pm 1.89$ & $2.87 \pm 0.56$ \\
& & $(30.7-57.1)$ & $(24.10-42.50)$ & $(22.90-32.70)$ & $(1.60-3.90)$ \\
type II & 36 & $39.84 \pm 3.25$ & $31.82 \pm 0.01$ & $27.73 \pm 1.35$ & $5.23 \pm 1.21$ \\
& & $(34.60-49.30)$ & $(26.40-40.50)$ & $(24.90-31.20)$ & $(4.10-7.80)$ \\
\hline
\end{tabular}



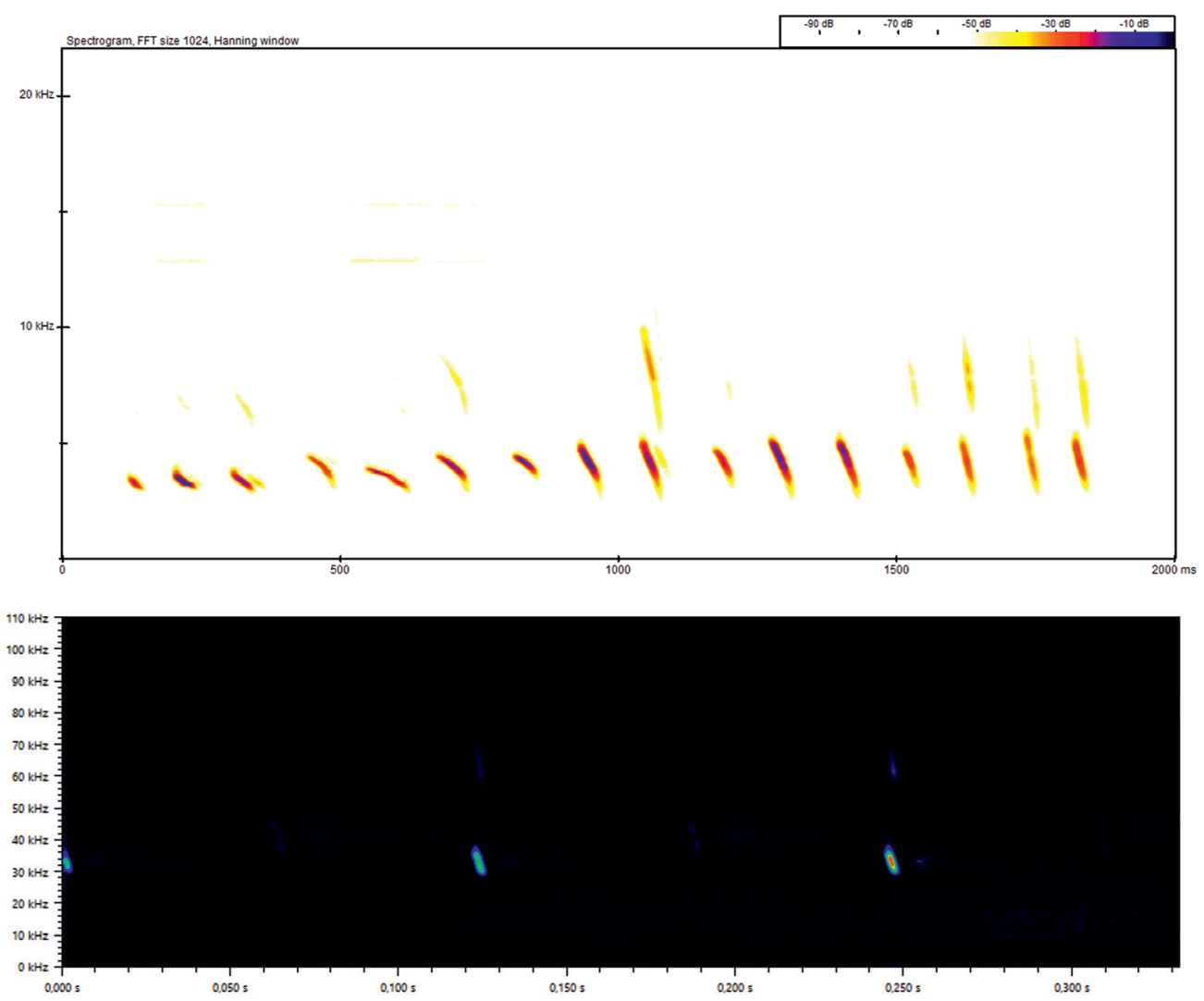

Fig. 6. The echolocation calls of Barbastella barbastellus from Turkey; spectrogram of a call recorded at Üçpınar (Çanakkale Province) on 19 June 2019 (top), sonogram of a call recorded at Babadağ (Denizli Province) on 30 October 2019 (bottom).

Obr. 6. Echolokační hlas d’asíka černého (Barbastella barbastellus) z Turecka; spektrogram výkřiku zaznamenaného 19. června 2019 u Üčpinaru v Dardanelské provincii (nahoře), sonogram hlasu nahraného 30. řrijna 2019 u Babadagu v Denizelské provincii (dole).

DENZINGER et al. (2001) reported that the call type II started at ca. $45 \mathrm{kHz}$ and ended at ca. $32 \mathrm{kHz}$, with a call duration of $6 \mathrm{~ms}$. However, their parameters varied according to habitat type. For example, the mean (min-max) values of duration were $6.79 \pm 1.36 \mathrm{~ms}(2.75-10.92 \mathrm{~ms})$ above roads, but $5.18 \pm 0.56 \mathrm{~ms}(2.88-9.38 \mathrm{~ms})$ in clearings. The same values for the signal type I were $2.7 \pm 0.53 \mathrm{~ms}(1.42-4.17 \mathrm{~ms})$ and $2.45 \pm 0.62 \mathrm{~ms}(1.46-4.38 \mathrm{~ms})$, respectively. Both recording localities in the Çanakkale and Denizli Provinces were openings surrounded by forests, with extensive vegetation clearings for wind farms. Therefore, DenZINGER et al. (2001) would be more appropriate to compare with the measurements given for clearings. According to the values given above, the echolocation calls we recorded in the Çanakkale and Denizli Provinces show similarity with those of B. barbastellus from Europe. 


\section{Threats}

The western barbastelle is globally listed as Near Threatened (NT) in the IUCN Red List (IUCN 2016); however, it is regionally listed as Vulnerable (VU) in Europe. Although its population size and trends are unknown in Turkey, major threats exist to this species and other bats, including Nyctalus noctula (Schreber, 1774), N. leisleri (Kuhl, 1817), and Myotis brandtii (Eversmann, 1845), which use forested areas as roost sites. These threats include habitat loss (cutting of old trees, renovation or demolition of old traditional buildings and their wooden window shutters that serve as the most popular roosting sites in the northern parts of the country, especially in the Rize Province, where the highest number of records comes from), fragmentation (caused by forestry, plateau tourism, and facility construction, mining etc.), disturbance (Dupnisa Cave is one of the most popular sites for cave tourism in Turkey and is visited by thousands of people every year; localities in the Nevşehir Province are artificial ancient caves, many of which are used by the local people as depositories and barns), and also wind turbines. Considering the above mentioned threats, this bat species should be listed as Vulnerable for Turkey.

\section{SOUHRN}

Ďasík černý, Barbastella barbastellus (Schreber, 1774) je druh netopýra chráněný mezinárodními dohodami a tureckými zákony. Počet záznamů o jeho rozšsiření v Turecku je velmi omezený a tento netopýr není v zemi př́liš známý. Většina nálezů uváděných v literatuře, s výjimkou nálezu ze sovího vývržku v provincii Adijaman a nálezů v provinciích Kırklareli a Neapolis (Nevşehir), pochází ze severovýchodního Turecka. Nově shromážděné nálezy dokládají, že je tento netopýr rozšířen převážně v provinciích podél jižního pobřeží Černého moře. Podle záznamů echolokačních hlasů byl však také prokázán v intravilánech v západním Turecku, v Dardanelské a Denizelské provincii. Poprvé byli jedinci d’asíka černého nalezeni v provinciích Parthenia (Bartın), Dardanely (Çanakkale), Denizli a Ikonium (Konya). Podle morfometrických údajů lze turecké populace zařadit k nominotypické (evropské) formě $B$. barbastellus barbastellus. Byly také analyzovány karyotpy několika jedinců, diploidní počet chromozomů činil $2 n=32$, s počty ramen $\mathrm{NF}=54$ a $\mathrm{NFa}=50 . \mathrm{V}$ textu jsou uvedeny také některé ekologické poznámky, spolu se analysou echolokačního hlasu.

\section{A c know le d g e ments}

I wish to thank Hasan KaRAKAYA, Arpat ÖZGüL, İbrahim Göktuğ KaRATAȘ, İbrahim Raşit BILgIN, Emrah Çoraman, Emek ÇELIK, Tayfun and his father Atila GüNERI for their help in collecting material, Emin SEYFI for sound analysis, Nizamettin YAVUZ for preparing the map, and Deniz CANDAS for proofreading and editing the English. This study was partially supported by the Research Fund of Niğde University (\# FEB 2001/023).

\section{REFERENCES}

BendA P. \& HoRÁČEK I., 1998: Bats (Mammalia: Chiroptera) of the Eastern Mediterranean. Part 1. Review of distribution and taxonomy of bats in Turkey. Acta Societatis Zoologicae Bohemicae, 62: 255-313.

Benda P. \& MlíkovsKÝ J., 2008: Nomenclatural notes on the Asian forms of Barbastella bats (Chiroptera: Vespertilionidae). Lynx, n. s., 39: 31-46.

Benda P., Ivanova T., Horáček I., Hanák V., Červený J., Gaisler J., Gueorguieva A., Petrov B. \& Vohralík V., 2003: Bats (Mammalia: Chiroptera) of the Eastern Mediterranean. Part 3. Review of bat distribution in Bulgaria. Acta Societatis Zoologicae Bohemicae, 67: 245-357.

Benda P., Dietz C., Andreas M., Hotový J., Lučan R. K., Maltby A., Meakin K., Truscott J. \& Vallo P., 2008: Bat s (Mammal ia: Chir opt era) of the East ern Medit er r anean and Middl e East. Part 6. Bat s of 
Sinai (Egypt) with some taxonomic, ecological and echolocation data on that fauna. Acta Societatis Zoologicae Bohemicae, 72: 1-103.

Benda P., Lučan R. K., Obuch J., Reiter A., Andreas M., BačKor P., Bohnenstengel T., Eid E. K., Ševčík M., Vallo P. \& AmR Z. S., 2010: Bats (Mammalia: Chiroptera) of the Eastern Mediterranean and Middle East. Part 8. Bats of Jordan: fauna, ecology, echolocation, ectoparasites. Acta Societatis Zoologicae Bohemicae, 74: 185-353.

Benda P., Faizolâhi K., Andreas M., Obuch J., Reiter A., Ševčí M., Uhrin M., Vallo P. \& Ashrafi S., 2012: Bats (Mammalia: Chiroptera) of the Eastern Mediterranean and Middle East. Part 10. Bat fauna of Iran. Acta Societatis Zoologicae Bohemicae, 76: 163-582.

Bovey R., 1949: Les chromosomes des chiroptères et des insectivores. Revue Suisse de Zoologie, 56: 371-460.

ÇAĞLAR M., 1969: Türkiye'nin yarasaları II [Turkish bats II]. Türk Biyoloji Dergisi, 19: 88-106 (in Turkish).

Capanna E., Conti L. \& De Renzis G., 1968: I cromosomi di Barbastella barbastellus (Mammalia - Chiroptera). Caryologia, 21: 137-145.

Denzinger A., Siemers B. M., Schaub A. \& Schnitzler H. U., 2001: Echolocation by the barbastelle bat, Barbastella barbastellus. Journal of Comparative Physiology A, 187: 521-528.

FEDYK S. \& RupreChT A. L., 1983: Chromosomes of some species of vespertilionid bats. II. Evolutionary relationships of plecotine bats. Acta Theriologica, 28: 171-182.

Ford G. E. \& HAMERTON J. L., 1956: A colchicine hypotonic-citrate, squash sequence for mammalian chromosomes. Stain Technology, 31: 247-254.

Hackett T. D., Holderied M. W. \& Korine C., 2016: Echolocation call description of 15 species of Middle-Eastern desert dwelling insectivorous bats. Bioacoustics, 26: 217-235.

von Helversen O., 1989: New records of bats (Chiroptera) from Turkey. Zoology in the Middle East, 3: $5-18$.

Hill J. E. \& Harrison D. L., 1987: The baculum in the Vespertilioninae (Chiroptera: Vespertilionidae) with a systematic review, a synopsis of Pipistrellus and Eptesicus, and the descriptions of a new genus and subgenus. Bulletin of the British Museum (Natural History), Zoology Series, 52: 225-305.

IUCN, 2016: Barbastella barbastellus. The IUCN Red List of Threatened Species 2016: e.T2553A22029285. URL: dx.doi.org/10.2305/IUCN.UK.2016-2.RLTS.T2553A22029285.en [accessed on 13 May 2020].

KarataŞ A., YiĞIT N., Çolak E. \& Kankiliç T., 2003: On the distribution, taxonomy and karyology of the genus Plecotus (Chiroptera: Vespertilionidae) in Turkey. Turkish Journal of Zoology, 27: 293-300.

Karataș A., YıĞıT N., Kankiliç T. \& ÇolaK E., 2004: Contribution to the distribution and karyology of some vespertilionid bats (Mammalia: Chiroptera) from Turkey. Zoology in the Middle East, 31: 5-12.

KRUSKOP S. V., 2015: Dark and pale: taxonomic status of the barbastelle (Barbastella: Vespertilionidae, Chiroptera) from Central Asia. Acta Chiropterologica, 17: 49-57.

Kumerloeve H., 1975: Die Säugetiere (Mammalia) der Türkei. Veröffentlichungen der Zoologischen Staatssammlung München, 18: 69-158 (in German).

López-Baucells A., 2019: 219. Western Barbastelle Barbastella barbastellus. Pp.: 860-861. WiLson D. E. \& Mittermeier R. A. (eds.): Handbook of Mammals of the World. Volume 9: Bats. Lynx Edicions, Barcelona, $1008 \mathrm{pp}$.

MacDonald D. \& Barrett P., 1993: Collins Field Guide to the Mammals of Britain and Europe. HarperCollins Publishers, New York, 448 pp.

Mitchell-Jones A. J., Amori G., Bogdanowicz W., Kryštufek B., Reijnders P. J. H., Spitzenberger F., Stubbe M., Thissen J. B. M., Vohralík V. \& Zima J., 1999: The Atlas of European Mammals. T \& AD Poyser Natural History, London, 484 pp.

Obrist M. K., Boesch R. \& FlüCKIGER P. F., 2004: Variability in echolocation call design of 26 Swiss bat species: Consequences, limits and options for automated field identification with a synergetic pattern recognition approach. Mammalia, 68: 307-322.

OвUсн J., 1994: K potrave výra skalného (Bubo bubo) a sovy obyčajnej (Strix aluco) vo východnej časti Turecka [On the food of the eagle owl (Bubo bubo) and tawny owl (Strix aluco) in the eastern part of Turkey]. Tichodroma, Bratislava, 7: 7-16 (in Slovak). 
Rydell J. \& Bogdanowicz W., 1997: Barbastella barbastellus. Mammalian Species, 557: 1-8.

Schober W. \& Grimmberger E., 1997: The Bats of Europe \& North America: Knowing Them, Identifying Them, Protecting Them. T.F.H. Publications, Inc., Neptune, 239 pp.

SiERro A., 1999: Habitat selection by barbastelle bats (Barbastella barbastellus) in the Swiss Alps (Valais). Journal of Zoology, London, 248: 429-432.

Steiner H. M. \& GAisler J., 1994: On a collection of bats (Chiroptera) from NE Turkey and N Iran. Acta Scientiarum Naturalium Academiae Scientiarum Bohemicae Brno, n. s., 28(1): 1-37.

TopÁl G., 1958: Morphological studies on the os penis of bats in the Carpathian Basin. Annales HistoricoNaturales Musei Nationalis Hungarici, N. S., 50: 331-342.

VAUGHAN N., JONES G. \& HaRris S., 1997: Identification of British bat species by multivariate analysis of echolocation call parameters. Bioacoustics, 7: 189-207.

Volleth M., 1985: Chromosomal homologies of the genera Vespertilio, Plecotus and Barbastella (Chiroptera: Vespertilionidae). Genetica, 66: 231-236.

VolLeth M., 1987: Differences in the location of nucleolus organizer regions in European vespertilionid bats. Cytogenetics and Cell Genetics, 44: 186-197.

Volleth M. \& Heller K.-G., 1994: Karyosystematics of plecotine bats: A reevaluation of chromosomal data. Journal of Mammalogy, 75: 416-419.

Whitaker J. O. Jr. \& KarataȘ A., 2009: Food and feeding habits of some bats from Turkey. Acta Chiropterologica, 11: 393-403.

Zima J., 1978: Chromosome characteristics of Vespertilionidae from Czechoslovakia. Acta Scientiarum Naturalium Academiae Scientiarum Bohemoslovacae Brno, n. s., 12(12): 1-38. 